\title{
Alkaloids from Chilean species of the genus Rhodophiala C. Presl (Amaryllidaceae) and their chemotaxonomic importance
}

\section{Alcaloides de especies chilenas del género Rhodophiala C. Presl (Amaryllidaceae) y su importancia quimiotaxonómica}

\author{
Isabel Lizama-Bizama ${ }^{1 *}$, Claudia Pérez ${ }^{1}$, Carlos M. Baeza ${ }^{1}$, Eugenio Uriarte ${ }^{2}$ \& José Becerra ${ }^{1}$ \\ 1Departamento de Botánica, Facultad de Ciencias Naturales y Oceanográficas, Universidad de Concepción, Casilla 160-C, \\ Concepción, Chile. \\ ${ }^{2}$ Departamento de Química Orgánica, Facultad de Farmacia, Universidad de Santiago de Compostela, 15782 Santiago de \\ Compostela, España. \\ *Corresponding author: ilizama@udec.cl
}

\begin{abstract}
The family Amaryllidaceae is widely distributed from temperate to tropical regions. Amaryllidaceae species from the subfamily Amaryllidoideae can biosynthesize alkaloids with important physiological effects. Rhodophiala C. Presl is one of the native genera of Amaryllidoideae of Chile, Argentina, Paraguay, Uruguay and Brazil. However, despite the diversity of this genus in Chile, their alkaloids have only been studied previously in one species of this country. The present work aims to analyze the alkaloid profiles and chemotaxonomically compare three other Chilean species of Rhodophiala: Rhodophiala bagnoldii (Herb.) Traub, Rhodophiala pratensis (Poepp.) Traub and Rhodophiala volckmannii Phil. Bulb extracts were analyzed by means of gas chromatography-mass spectrometry (GC-MS) and alkaloids were characterized according to retention time and fragmentation pattern. The skeleton type alkaloids detected were lycorine, crinine, galanthamine, homolycorine, tazettine and montanine. All analyzed species showed different alkaloid profiles, indicating these compounds can be used as a chemotaxonomic tool. Furthermore, the alkaloid types detected in this genus have multiple reported biological properties and these species can constitute new sources of important medicinal products.
\end{abstract}

KeYwords: Alkaloids, Chilean species of Amaryllidaceae, GC-MS, Rhodophiala.

\section{RESUMEN}

La familia Amaryllidaceae está ampliamente distribuida desde regiones templadas a tropicales. Las especies de la subfamilia Amaryllidoideae biosintetizan alcaloides con importantes efectos fisiológicos. Rhodophiala C. Presl es uno de los géneros nativos de Amaryllidoideae de Chile, Argentina, Paraguay, Uruguay y Brasil. Sin embargo, a pesar de la diversidad de este género en Chile, sólo se han estudiado los alcaloides de una especie de este país. En este trabajo se analiza el perfil alcaloideo y se comparan quimiotaxonómicamente otras tres especies chilenas del género Rhodophiala: Rhodophiala bagnoldii (Herb.) Traub, Rhodophiala pratensis (Poepp.) Traub y Rhodophiala volckmannii Phil. Se analizaron extractos de bulbos mediante cromatografía de gases-espectrometría de masas (CG-EM). Los alcaloides fueron caracterizados por su tiempo de retención y patrón de fragmentación. Los tipos de esqueletos de los alcaloides detectados fueron licorina, crinina, galantamina, homolicorina, tazetina y montanina. Todas las especies analizadas presentaron diferentes perfiles alcaloideos, por lo que estos compuestos pueden ser usados como una herramienta quimiotaxonómica. Además, los tipos de alcaloides detectados en este género tienen múltiples propiedades biológicas reportadas en literatura y estas especies pueden constituir nuevas fuentes de productos de importancia medicinal.

Palabras clave: Alcaloides, especies chilenas de Amaryllidaceae, CG-EM, Rhodophiala.

\section{INTRODUCTION}

The family Amaryllidaceae has three subfamilies: Amaryllidoideae, Agapanthoideae and Allioideae (Chase et al. 2009). Species of the subfamily Amaryllidoideae are widely known for biosynthesis of pharmacologically active alkaloids, including antitumor, antiviral, antimalarial and immunostimulant activity; as well as inhibition of the acetylcholinesterase enzyme (Bastida et al. 2011, Ding et al. 2017). These alkaloids are named Amaryllidaceae 
alkaloids and classified into nine skeleton types, for which the representative alkaloids are: norbelladine, lycorine, homolycorine, crinine, haemanthamine, narciclasine, tazettine, montanine and galanthamine (Bastida et al. 2011).
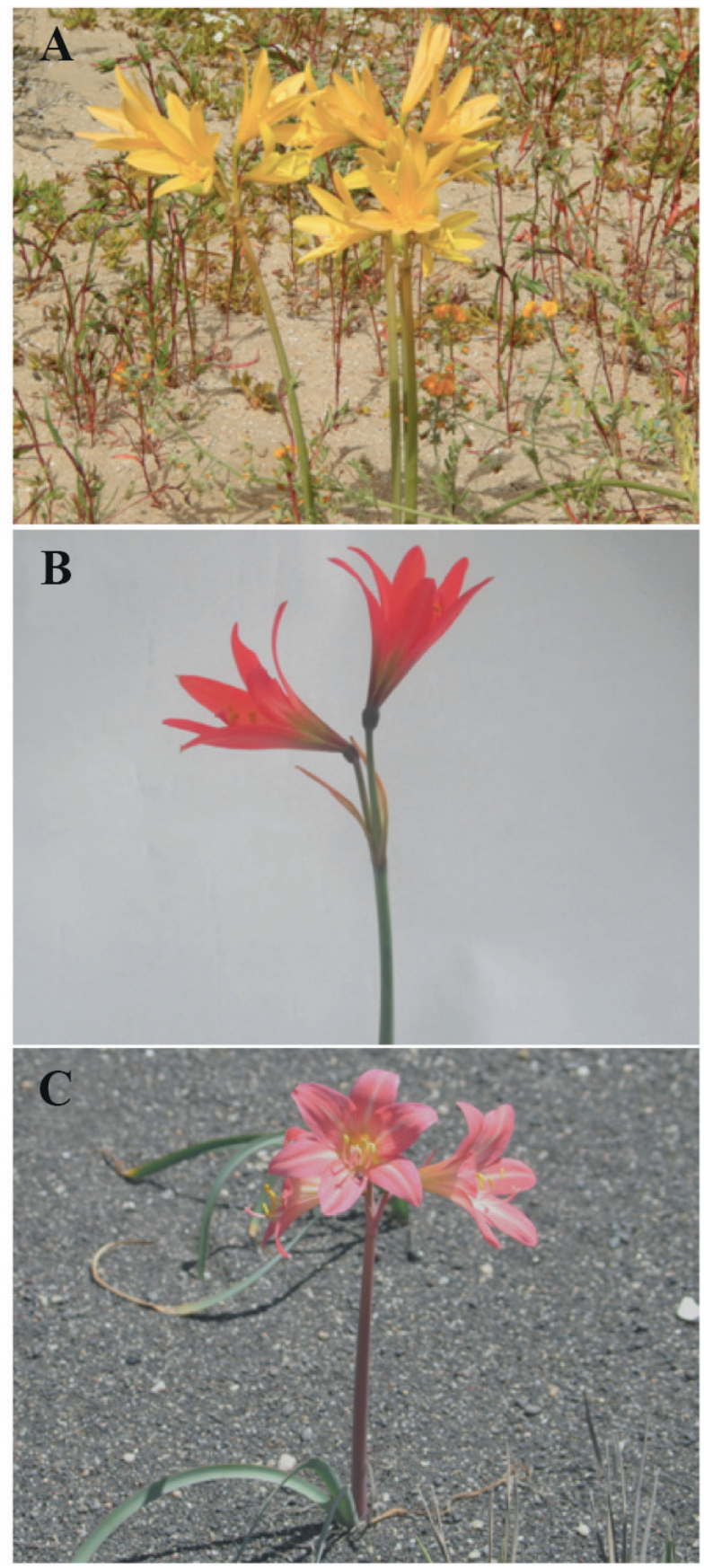

FIGURE 1. (A) R. bagnoldii in its natural habitat. (B) Flowers of $R$. pratensis. (C) $R$. volckmannii in its natural habitat (A and C: Photos by C. M. Baeza. B: Photo by I. Lizama-Bizama). / (A) $R$. bagnoldii en su hábitat natural. (B) Flores de R. pratensis. (C) $R$. volckmannii en su hábitat natural (A y C: Fotografías de C. M. Baeza. B: Fotografía de I. Lizama-Bizama).
There are more than 30 native species of the subfamily Amaryllidoideae in Chile, from Arica and Parinacota Region to Los Lagos Region (latitude $18^{\circ} \mathrm{S}$ to $43^{\circ} \mathrm{S}$ ) and with a wide altitudinal distribution (Ravenna 2003, ArroyoLeuenberger \& Dutilh 2008).

Rhodophiala C. Presl is one of the native genera of Chile, and is also distributed in Argentina, Brazil, Paraguay and Uruguay (Arroyo-Leuenberger \& Dutilh 2008). In Chile, Rhodophiala species are found in the coastal desert and semidesert areas, in the coastal mountain range, the central valley and the plains and hills of the foothills and mountains of the Andes, between Antofagasta Region and Los Lagos Region (Schiappacasse et al. 2002). This genus is characterized by a funnel-shaped perigon of 6 tepals; an androecium of 6 slightly unequal stamens, and a tricarpellary gynoecium of inferior ovary, terminating in a trifid stigma (Baeza et al. 2012). It also presents flowers of red, pink, orange and yellow. These plants have high ornamental value, with many lesser-known species, some of which even have conservation problems (Muñoz et al. 2009).

Despite the variety of Amaryllidoideae species in Chile, only two species have been chemically studied (Pacheco et al. 1978, 1981, 1982, Sepúlveda et al. 1982, Pacheco \& Silva 1992). The chemistry knowledge of these species can help to solve taxonomic problems of Chilean Amaryllidoideae due to their complex morphological variation (Baeza et al. 2009, Fuentes et al. 2007). In fact, the Rhodophiala genus requires an urgent taxonomic revision due to doubts about the identification of several populations (Baeza et al. 2016).

Considering the limited knowledge on secondary metabolites regarding these native plants and the varied backgrounds on the biological activity of their alkaloids, in this work we analyze the alkaloid profiles for three species of this genus: Rhodophiala bagnoldii (Herb.) Traub, Rhodophiala pratensis (Poepp.) Traub and Rhodophiala volckmannii Phil. (Fig. 1). R. bagnoldii lives in sandy coastal and inland areas from southern Antofagasta Region to the Coquimbo Region (Schiappacasse et al. 2002). $R$. volckmannii is located on the coast near Cobquecura, in the Bío-Bío Region (Muñoz-Schick 1973). Meanwhile, $R$. pratensis preferably grows in sandy soils of the Andean Precordillera of the Maule and Bío-Bío Regions (Baeza et al. 2012). Thus, the main objective of this research was to chemotaxonomically differentiate these species, contributing chemical characters to the taxonomy of this genus.

\section{MATERIALS AND METHODS}

Plant MATERIAL

Plants of Rhodophiala bagnoldii, $R$. pratensis and $R$. volckmannii were collected. $R$. bagnoldii was collected in CHILE, Atacama Region, Huasco Province, $102 \mathrm{~m}$ (2824'45"S-71¹0'54"'W), 19-X-2011, I. Lizama- 
Bizama 9. R. pratensis was collected in CHILE, BíoBío Region, Bío-Bío Province, road to Antuco, $368 \mathrm{~m}$ (37²4'37'S-7157'14'”W), 27-I-2011, I. Lizama-Bizama w/n. R. volckmannii was collected in CHILE, Bío-Bío Region, Valle del Itata Province, Colmuyao beach, near Cobquecura, $16 \mathrm{~m}$ (3609'08'S-7248'21'W), 15-XII2010, I. Lizama-Bizama w/n. Collections were performed during the flowering periods of these species. Specimens were deposited at the herbarium of the University of Concepción (CONC), Concepción, Chile. Bulbs were separated from the flower scapes, leaves and roots, and then minced for maceration.

\section{AlKALOID EXTRACTION}

Fresh bulbs (90 g of $R$. pratensis, $114 \mathrm{~g}$ of $R$. volckmannii and $430 \mathrm{~g}$ of $R$. bagnoldii) were macerated in $0.1 \mathrm{~N} \mathrm{HCl}$ at room temperature for $72 \mathrm{~h}$. The raw extracts were defatted three times with $\mathrm{CH}_{2} \mathrm{Cl}_{2}$. The solvent was evaporated under reduced pressure. These extracts were then basified with $25 \%$ ammonia solution and the alkaloids extracted with $\mathrm{CH}_{2} \mathrm{Cl}_{2}$. The organic solvent was evaporated and yielded the following extracts: $37 \mathrm{mg}$ of $R$. pratensis, $23 \mathrm{mg}$ of $R$. volckmannii and $266 \mathrm{mg}$ of $R$. bagnoldii. Each alkaloid extract was dissolved in $\mathrm{CHCl}_{3}$ to a final concentration of $10 \mathrm{mg} / \mathrm{mL}$ for further analysis.

\section{GC-MS ANALYSIS}

The GC-MS analysis of underivatized alkaloids was carried out on a gas chromatograph (Agilent 7890A) with a splitless injector $\left(250^{\circ} \mathrm{C}\right)$ and a mass detector (Agilent 5975C). An HP-5MS capillary column $(30 \mathrm{~m} \times 0.25 \mathrm{~mm} \times 0.25 \mu \mathrm{m})$ and helium gas (constantflow $1 \mathrm{~mL} / \mathrm{min}$ ) were used for separation.
The temperature program was: $5 \mathrm{~min}$ hold at $100{ }^{\circ} \mathrm{C}, 100$ $275^{\circ} \mathrm{C}$ at $13{ }^{\circ} \mathrm{C} / \mathrm{min}$ and $32 \mathrm{~min}$ hold at $275^{\circ} \mathrm{C}$. Detection range was $m / z$ 50-550. The injector temperature was 250 ${ }^{\circ} \mathrm{C}$. Tentative identification of the alkaloid components was accomplished by matching mass spectra to records in the NIST 05 (NIST /EPA/NIH MASS 2005 Spectral Library) and by comparing the obtained spectra with those reported in the literature. NIST 05 collects representative alkaloids of all the skeletons referenced. The structure of an alkaloid is tentatively assigned when the overlap with the database exceeds $90 \%$. Skeletons of unidentified compounds were proposed according to the highest index of similarity with those listed in the database. Furthermore, a standard was used for galanthamine identification.

Percentage of the compounds in the extracts was calculated based on the total area of the GC-MS peaks (Berkov et al. 2008).

\section{RESULTS}

A total of 25 compounds with mass spectral characteristics of Amaryllidaceae alkaloids were found in the bulbs of the studied species (Table 1). Seventeen were found in $R$. bagnoldii (Fig. 2), seven in R. pratensis and four in $R$. volckmannii. The retention time of alkaloids was between 18 and 24 min.

Each analyzed species showed a distinct alkaloid profile. In addition, all these species share tazettine. Only $R$. bagnoldii and $R$. pratensis share crinan-3-one. Major alkaloids for the three species were montanine type: A10 in $R$. bagnoldii, montanine in $R$. pratensis and A19 in $R$. volckmannii (Table 1).

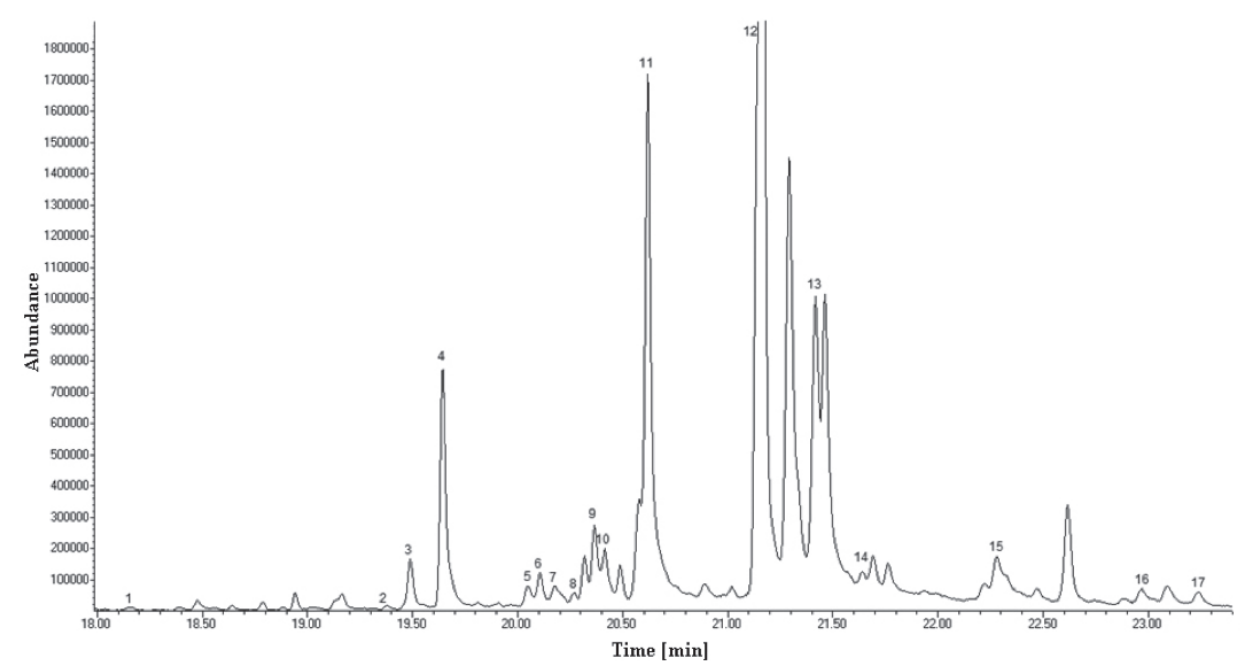

FiguRE 2. Representative chromatogram of extract for R. bagnoldii. 1: A1. 2: A2. 3: Galanthamine. 4: A3. 5: 1,2-didehydro-(3ß)-Crinan-3ol. 6: A4. 7: A5. 8: A6. 9: A7. 10: A8. 11: A9. 12: A10. 13: Tazettine. 14: A11. 15: Lycorine. 16: A12. 17: Crinan-3-one. / Cromatograma representativo del extracto de R. bagnoldii. 1: A1. 2: A2. 3: Galantamina. 4: A3. 5: 1,2-didehidro-(3ß)-Crinan-3-ol. 6: A4. 7: A5. 8: A6. 9: A7. 10: A8. 11: A9. 12: A10. 13: Tazetina. 14: A11. 15: Licorina. 16: A12. 17: Crinan-3-ona. 
Gayana Bot. 75(1), 2018

TABLE 1. Alkaloids in species of the genus Rhodophiala. / Alcaloides en especies del género Rhodophiala.

\begin{tabular}{|c|c|c|c|}
\hline $\mathrm{RT}^{\mathrm{a}}$ & AlKaloid (SKeLETON TYPE) & $m / z$ (\% RELATIVE INTENSITY $)$ & $\%^{\mathrm{b}}$ \\
\hline \multicolumn{4}{|c|}{ Rhodophiala bagnoldii: } \\
\hline 18.16 & A1 (Lycorine) & $\begin{aligned} 269(56), 268 \text { (100), } 241(17), 224(23), 209 \text { (14), } 207(21), 196(15), \\
182(16), 167(19), 84 \text { (15) }\end{aligned}$ & 0.09 \\
\hline 19.38 & A2 (Montanine) & $\begin{array}{c}315(87), 285(53), 284(55), 281(33), 268(45), 207(63), 134(100), \\
132(55), 96(36), 70(40)\end{array}$ & 0.10 \\
\hline 19.49 & Galanthamine * (Galanthamine) & $\begin{array}{c}288(15), 287(79), 286(100), 270(16), 244(27), 230(12), 216(38), \\
174(33), 128(11), 115(16)\end{array}$ & 1.17 \\
\hline 19.65 & A3 (Galanthamine) & $\begin{array}{c}290 \text { (10), } 289 \text { (59), } 288 \text { (100), } 232(7), 213(6), 202(10), 189 \text { (7), } 188 \\
\text { (8), } 187(9), 115(10)\end{array}$ & 5.05 \\
\hline 20.05 & 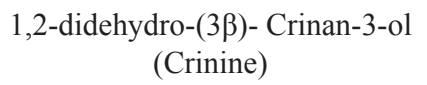 & $\begin{array}{c}271 \text { (100), } 254 \text { (25), } 252(27), 228(28), 200(26), 199(80), 187 \text { (65), } \\
173(25), 128(27), 115(29)\end{array}$ & 0.47 \\
\hline 20.10 & A4 (Homolycorine) & $\begin{array}{c}285 \text { (2), } 284 \text { (2), } 207 \text { (5), } 115(2), 110(9), 109 \text { (100), } 108(17), 94 \text { (4), } \\
93(2), 77(2)\end{array}$ & 0.60 \\
\hline 20.18 & A5 (Tazettine) & $\begin{array}{c}315(20), 300(44), 232(25), 231(100), 230(19), 207(18), 185(17) \\
115(21), 109(59), 70(68)\end{array}$ & 0.48 \\
\hline 20.27 & A6 (Crinine) & $\begin{array}{c}303(100), 302(26), 272(46), 242(22), 218(37), 217(38), 216(20), \\
207(23), 202(21), 201(30)\end{array}$ & 0.15 \\
\hline 20.36 & A7 (Crinine) & $\begin{array}{c}288(23), 287 \text { (97), } 244(35), 217(20), 216(27), 215(100), 203(58), \\
189(22), 128(22), 115(25)\end{array}$ & 1.57 \\
\hline 20.41 & A8 (Montanine) & $\begin{array}{c}301(100), 271 \text { (38), } 254(53), 252(33), 212(31), 199(43), 185 \text { (68), } \\
141(35), 128(31), 115(38)\end{array}$ & 1.06 \\
\hline 20.62 & A9 (Crinine) & $\begin{aligned} & 290(19), 289(100), 288(27), 272(21), 260(23), 218(47), 217(35), \\
& 216(18), 202(23), 201(24)\end{aligned}$ & 14.48 \\
\hline 21.17 & A10 (Montanine) & $\begin{array}{c}319(23), 301(100), 270(88), 257(36), 229(24), 226(28), 223(26), \\
199(21), 185(31), 115(22)\end{array}$ & 27.23 \\
\hline 21.42 & Tazettine (Tazettine) & $\begin{array}{c}331(24), 298(18), 248(16), 247(100), 201(16), 199(15), 181 \text { (13), } \\
115(15), 71(21), 70(23)\end{array}$ & 7.27 \\
\hline 21.64 & A11 (Lycorine) & $\begin{array}{c}305(16), 301(15), 300(14), 252(14), 250(16), 228(18), 227(78), 226 \\
(100), 207(22), 147(17)\end{array}$ & 0.47 \\
\hline 22.28 & Lycorine (Lycorine) & $\begin{array}{c}287(19), 286(16), 268(20), 250(16), 242(11), 228(13), 227 \text { (63), } 226 \\
(100), 207(11), 147(11)\end{array}$ & 1.77 \\
\hline 22.97 & A12 (Homolycorine) & $\begin{array}{c}281(3), 207(7), 193(2), 165(2), 110(10), 109(100), 108(18), 94(2), \\
82(3), 81(2)\end{array}$ & 0.48 \\
\hline 23.24 & Crinan-3-one (Crinine) & $\begin{array}{c}284(25), 281(17), 271(100), 270(55), 240(20), 211(21), 207(37) \\
181(57), 153(17), 152(21)\end{array}$ & 0.39 \\
\hline \multicolumn{4}{|c|}{ Rhodophiala pratensis: } \\
\hline 19.99 & A13 (Homolycorine) & $\begin{array}{c}135 \text { (5), } 117 \text { (7), } 110(10), 109 \text { (100), } 108 \text { (16), } 81 \text { (5), } 71 \text { (4), } 67 \text { (4), } 57 \\
(8), 55(7)\end{array}$ & 1.06 \\
\hline 20.06 & A14 (Tazettine) & $\begin{array}{c}315(18), 300(38), 231 \text { (100), } 135(27), 115(25), 109(27), 91(19), 70 \\
\text { (79), } 57(19), 55(27)\end{array}$ & 0.57 \\
\hline 20.23 & A15 (Crinine) & $\begin{array}{c}269(100), 240(33), 212(27), 186(91), 185(45), 135(29), 128(71) \\
127(31), 115(34), 55(35)\end{array}$ & 0.51 \\
\hline 20.79 & A16 (Crinine) & $\begin{array}{c}295(24), 271(100), 270(44), 211(24), 181(85), 153(27), 152(31), \\
135(26), 94(38), 55(25)\end{array}$ & 0.66 \\
\hline 21.07 & Montanine (Montanine) & $\begin{array}{c}302(23), 301(100), 270(91), 257(36), 229(26), 226(31), 223(29), \\
185(36), 128(24), 115(28)\end{array}$ & 5.90 \\
\hline 21.29 & Tazettine (Tazettine) & $\begin{array}{c}331(22), 298(17), 248(16), 247(100), 201(18), 199(16), 181(16), \\
115(23), 71(26), 70(29)\end{array}$ & 2.07 \\
\hline 23.06 & Crinan-3-one (Crinine) & $\begin{array}{c}272(21), 271(100), 270(44), 207(29), 181(65), 135 \text { (29), } 91(25), 81 \\
(21), 67(24), 55(30)\end{array}$ & 0.30 \\
\hline
\end{tabular}




\begin{tabular}{|c|c|c|c|}
\hline $\mathrm{RT}^{\mathrm{a}}$ & AlKaloid (SKeleton tYPe) & $m / z$ (\% RELATIVE INTENSITY) & $\% \mathrm{~b}$ \\
\hline \multicolumn{4}{|c|}{ Rhodophiala volckmannii: } \\
\hline 18.08 & A17 (Lycorine) & $\begin{array}{c}269(55), 268(100), 135(20), 91(22), 83(21), 77(16), 69(19), 67 \\
(17), 57(17), 55(28)\end{array}$ & 0.56 \\
\hline 20.23 & A18 (Crinine) & $\begin{array}{c}269(92), 186(91), 135 \text { (78), } 128(68), 91(59), 83(58), 81(64), 69 \\
(69), 57(56), 55(100)\end{array}$ & 0.28 \\
\hline 21.08 & A19 (Montanine) & $\begin{array}{c}301(100), 270(94), 257(36), 223(40), 207(36), 185(47), 135(46), \\
115(43), 77(37), 55(56)\end{array}$ & 2.02 \\
\hline 21.29 & Tazettine (Tazettine) & $\begin{array}{c}331(25), 298(22), 248(21), 247(100), 135(23), 115(30), 71(33), 70 \\
(33), 57(24), 55(26)\end{array}$ & 1.08 \\
\hline
\end{tabular}

aRetention time (min). / Tiempo de retención ( $\mathrm{min})$.

bercentage of the compound in the extract. Values are expressed as a percentage of the total ion chromatogram. / Porcentaje del compuesto en el extracto. Los valores están expresados como un porcentaje del cromatograma total de iones.

*Comparison with a standard MS spectra. / Comparación con un espectro EM estándar.

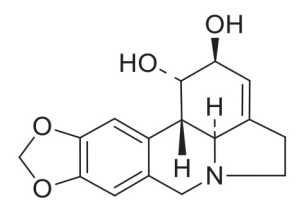

Lycorine

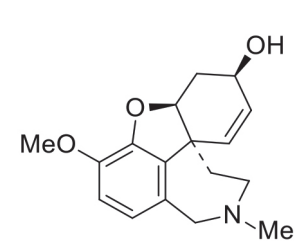

Galanthamine

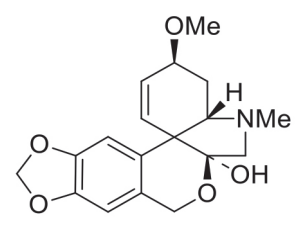

Tazettine
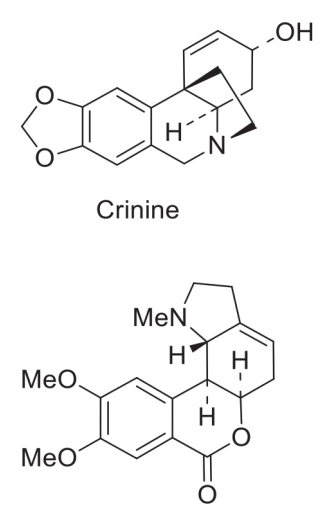

Homolycorine

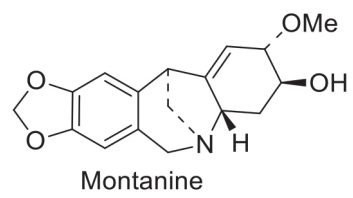

Figure 3. Types of Amaryllidaceae alkaloids identified in the extracts: lycorine, crinine, galanthamine, homolycorine, tazettine and montanine. / Tipos de alcaloides de Amaryllidaceae identificados en los extractos: licorina, crinina, galantamina, homolicorina, tazetina y montanina.

The skeleton type alkaloids detected were tentatively identified as lycorine, crinine, galanthamine, homolycorine, tazettine and montanine (Fig. 3, Table 2). R. bagnoldii bulbs had the highest variety of skeleton types. Galanthamine-type alkaloids were present only in $R$. bagnoldii. $R$. pratensis presented crinine-type and homolycorine-type alkaloids, in addition to tazettine-type and montanine-type alkaloids. Meanwhile, only $R$. volckmannii and R. bagnoldii presented lycorine-type alkaloids.
TABLE 2. Presence of different types of Amaryllidaceae alkaloids in the studied species. / Presencia de los diferentes tipos de alcaloides de Amaryllidaceae en las especies estudiadas.

\begin{tabular}{lccc}
\hline SKELETON TYPE & R. BAGNOLDII & R. PRATENSIS & R. VOLCKMANNII \\
\hline CRININE & $\checkmark$ & $\checkmark$ & $\checkmark$ \\
GALANTHAMINE & $\checkmark$ & - & - \\
HoMOLYCORINE & $\checkmark$ & $\checkmark$ & - \\
LYCORINE & $\checkmark$ & - & $\checkmark$ \\
MONTANINE & $\checkmark$ & $\checkmark$ & $\checkmark$ \\
TAZETTINE & $\checkmark$ & $\checkmark$ & $\checkmark$ \\
\hline
\end{tabular}

\section{DISCUSSION}

Three species of Rhodophiala, R. bagnoldii, R. pratensis and $R$. volckmannii, share alkaloids with crinine, tazettine and montanine skeleton types (Table 2). The presence of these three skeleton types could be characteristic of the Rhodophiala genus, in comparison to other genera of Chilean Amaryllidoideae. Thus, the Amaryllidaceae alkaloids could allow to differentiate Chilean Amarylloideae genera. On the other hand, only $R$. bagnoldii presented galanthamine-type alkaloids. The exclusive galanthaminetype alkaloids detected in $R$. bagnoldii could allow it to be chemotaxonomically differentiated. Lycorine-type alkaloids were absent only in $R$. pratensis, and homolycorinetype alkaloids were absent only in $R$. volckmannii. The 
absence and presence of these alkaloid types can be used as a chemotaxonomic tool for differentiating Rhodophiala species.

$R$. bagnoldii presents more morphological differences compared to the other two species studied and has a more distant geographical distribution in northern Chile. This species presents flowers with infundibuliform perigonium, of pure yellow color, or with orange lines and the greenish base of the tube (Schiappacasse et al. 2002). In contrast, $R$. pratensis and $R$. volckmannii are both located in the BíoBío Region of central Chile and have similar morphological characters. $R$. pratensis presents red scarlet flowers, sometimes yellowish (Baeza et al. 2012), and the studied population of $R$. volckmannii presents pale red and more bell-shaped flowers. The morphological differences and similarities between these three species are concordant with the characteristics of their alkaloid profiles: $R$. pratensis and $R$. volckmannii present greater similarity in their types of alkaloids, in comparison with $R$. bagnoldii. It is necessary to analyze more species of this genus to corroborate if they also differ in their types of Amaryllidaceae alkaloids. If there were no major differences between the types of alkaloids of all Chilean Rhodophiala species, these compounds could also have chemotaxonomic importance at the genus level, and thus contribute to the resolution of the taxonomic problem of the Chilean Amaryllidoideae.

According to previous studies, lycorine-type, homolycorine-type and haemanthamine-type alkaloids were found in the Chilean species Rhodophiala ananuca (= Hippeastrum ananuca) (Pacheco et al. 1982). In our study, only haemanthamine-type alkaloids were not found in the three analyzed species. Crinine-type, tazettine-type and montanine-type alkaloids shared by $R$. bagnoldii, $R$. pratensis and $R$. volckmannii, were not detected in the species studied by Pacheco et al. 1982. Our study is the first to analyze alkaloids of Chilean Rhodophiala by GCMS. This method is efficient and reliable for studies on Amaryllidaceae alkaloids (Berkov et al. 2008).

Furthermore, it is important to mention that the alkaloid types identified in this genus have multiple and documented biological properties, and therefore these species can constitute new sources for products of medicinal importance.

\section{ACKNOWLEDGMENTS}

The first author was funded by CONICYT Scholarship for Doctorate studies in Chile, CONICYT Scholarship for ending Thesis, MECESUP Scholarship (UCO0708) for a Doctoral Internship abroad and with the funding from the Vice-rectory of Research and Development, University of Concepción.

\section{REFERENCES}

Arroyo-Leuenberger, S., Dutilh, J. 2008. Amaryllidaceae. In: Zuloaga, F., Morrone, O., Belgrano, M. (eds.), Catálogo de las Plantas Vasculares del Cono Sur, Vol. I, pp. 203226. Monographs in Systematic Botany from the Missouri Botanical Garden 107, USA.

Baeza, C.M., Mariangel, C., Ruiz, E., Negritto, M. 2009. El cariotipo fundamental en Rhodolirium speciosum (Herb.) Ravenna y $R$. andicola (Poepp.) Ravenna (Amaryllidaceae). Gayana Botánica 66(1): 99-102.

Baeza, C., Almendras, F., Ruiz, E., Peñailillo, P. 2012. Estudio comparativo del cariotipo en especies de Miltinea Ravenna, Phycella Lindl. y Rhodophiala C. Presl (Amaryllidaceae) de Chile. Revista de la Facultad de Ciencias Agrarias, Universidad Nacional de Cuyo 44(2): 193-205.

Baeza, C. M., Peñailillo, P., Novoa, P., Rosas, M., Finot, V.L., Ruiz, E. 2016. Recuentos cromosómicos en plantas que crecen en Chile. IV. Gayana Botánica 73(2): 183-190.

Bastida, J., Berkov, S., Torras, L., Pigni, N.B., de Andrade, J.P., Martínez, V., Codina, C., Viladomat, F. 2011. Chemical and biological aspects of Amaryllidaceae alkaloids. In: Muñoz-Torrero, D. (ed.), Recent Advances in Pharmaceutical Sciences, pp. 65-100. Transworld Research Network, Kerala, India.

Berkov, S., Bastida, J., Sidjimova, B., Viladomat, F., Codina, C. 2008. Phytochemical differentiation of Galanthus nivalis and Galanthus elwesii (Amaryllidaceae): A case study. Biochemical Systematics and Ecology 36: 638-645.

Chase, M.W., Reveal, J.L., Fay, M.F. 2009. A subfamilial classification for the expanded asparagalean families Amaryllidaceae, Asparagaceae and Xanthorrhoeaceae. Botanical Journal of the Linnean Society 161: 132-136.

Ding, Y., Qu, D., Zhang, K.M., Cang, X.X., Kou, Z.N., XIaO, W., ZHu, J.B. 2017. Phytochemical and biological investigations of Amaryllidaceae alkaloids: a review. Journal of Asian Natural Products Research 19(1): 53-100.

Fuentes, L., Schiappacasse, F., Herrera, R., Peñailillo, P., Vogel, H. 2007. Evaluación preliminar de las relaciones interespecíficas en Rhodophiala Presl. (Amaryllidaceae) mediante marcadores moleculares ISSR. Agro Sur 35(2): 47-49.

Muñoz, M., Seemann, P., Jara, G., Riegel, R. 2009. Influence of vessel type, physical state of medium and temporary immersion on the micropropagation of three Rhodophiala species. Chilean Journal of Agricultural Research 69(4): 581-587.

MuÑoz-Schick, M. 1973. Complemento de "Las especies de plantas descritas por R.A. Philippi en el siglo XIX". Anales Universidad de Chile, serie 3, 128: 5-69.

Pacheco, P., Silva, M. 1992. Amaryllidaceae. In: Muñoz, O. (ed.), Química de la flora de Chile, Serie de programas de desarrollo, Vol. 1, pp. 309-319. Departamento Técnico de Investigación, Universidad de Chile, Chile.

Pacheco, P., Silva, M., Kimura, M., Watson, W.H. 1981. Proanthocyanidins of Hippeastrum ananuca I. Revista Latinoamericana de Química 12(1): 30-32.

Pacheco, P., Silva, M., Sammes, P.G., Watson, W.H. 1982. Estudio químico en Amaryllidaceae chilenas II. Nuevos alcaloides de Hippeastrum ananuca Phil. Boletín de la Sociedad 
Alkaloids from Chilean species of the genus Rhodophiala: LizAmA-BizAMA, I. ET AL.

Chilena de Química 27(2): 289-290.

Pacheco, P., Silva, M., Steglich, W., Watson, W.H. 1978. Alkaloids of Chilean Amaryllidaceae hippeastidine and epi-homolycorine. Revista Latinoamericana de Química 9: 28-32.

Ravenna, P. 2003. Elucidation and systematics of the Chilean genera of Amaryllidaceae. Botanica Australis 2: 1-21.

Schiappacasse, F., Peñailillo, P., Yáñez, P. 2002. Propagación de bulbosas chilenas ornamentales. Editorial Universidad de Talca, Chile. 65 pp.

Sepúlveda, B.A., Pacheco, P., Silva, M.J., Zemelman, R. 1982. Alcaloides de Amarillidaceas chilensis III. Estudio químico y actividad biológica en Hippeastrum bicolor ( $\mathrm{R}$. et P.) Baker. Boletín de la Sociedad Chilena de Química 27(2): 178-180.

Recibido: 25.10 .2017

Aceptado: 08.03.2018 